\section{Challenges of gaming disorder: suggestions from a public health perspective}

\author{
Min Zhao (D) , 'Wei Hao ${ }^{2}$
}

Based on the results from numerous studies and discussions by expert groups organised by the WHO, gaming disorder is recognised as a mental disorder and is listed in the chapter of mental, behavioural and neurodevelopmental disorders in the recently released International Classification of Diseases, 11th Version (ICD-11). ${ }^{1}$ Gaming disorder, gambling disorder and substance use disorder belong to the same category of mental disorder. This change will help improve the public's awareness and understanding of gaming disorder. Meanwhile, it will encourage related research and develop scientific and effective interventions for the purpose of negative consequences reduction.

\section{CORE CLINICAL FEATURES OF GAMING DISORDER}

The proposed diagnostic guidelines for gaming disorder in ICD-11 are listed as follows: (1) a pattern of persistent or recurrent gaming behaviour ('digital gaming' or 'video-gaming'), which may be predominantly online (ie, over the internet or similar electronic networks) or offline, manifested by all of the following: impaired control over gaming behaviour (ie, onset, frequency, intensity, duration, termination, context); increasing priority given to gaming to the extent that gaming takes precedence over other life interests and daily activities; and continuation or escalation of gaming despite the occurrence of negative consequences (eg, repeated relationship

\footnotetext{
${ }^{1}$ Shanghai Mental Health Center, Shanghai Jiao Tong University School of Medicine, Shanghai, China ${ }^{2}$ Mental Health Institute, Second Xiangya Hospital, Central South University, Changsha, China
}

Correspondence to Dr Min Zhao, Shanghai Mental Health Center, Shanghai 200030, China; drminzhao@smhc.org.cn disruption, occupational or academic consequences, negative impact on health); (2) the pattern of gaming behaviour may be continuous or episodic and recurrent, but is manifested over an extended period of time (eg, 12 months); (3) the pattern of gaming behaviour results in marked distress or significant impairment in personal, family, social, educational, occupational or other important areas of functioning.

\section{RELATED FACTORS AND NEGATIVE CONSEQUENCES OF GAMING DISORDER}

Studies have found that gaming disorder presents similar clinical characteristics and brain neuroimaging changes as substance dependence. ${ }^{2}$ Gaming disorder has a series of physiological, psychological and family social problems. ${ }^{3} 4$ The impact on physical health is mainly related to the unhealthy lifestyle of game players. They indulge in gaming most of the day, have an irregular lifestyle, lack exercise and their physical health declines. Many people with gaming disorder are addicted to games due to various psychological or family problems, and gaming disorder aggravates their psychological problems. In severe cases, they may also suffer from depression, anxiety and even psychotic disorders, which seriously affect their normal learning, family and social functions. Many teenagers give up their schooling due to gaming disorder. ${ }^{56}$ Gaming disorder is also comorbid with many mental disorders, and affects its occurrence and development mutually.

Since the occurrence and development of gaming disorder are closely related to individual psychological, family and social factors, affecting individual physical, psychological, family and social functions, comprehensive strategies including medical, psychological, family and social intervention are needed to prevent and reduce the harm of gaming disorder. ${ }^{7}$

\section{SUGGESTIONS FROM A PUBLIC HEALTH PERSPECTIVE}

Gaming disorder is a public health issue with many factors related to psychological, family and social factors. The following items are suggested to prevent gaming disorder and control its negative consequences: (1) teenagers are the high-risk group for gaming disorder and they should be the targeted population of the prevention programmes. The prevention should be carried out jointly by related parties including schools, parents and related social organisations and focus on increasing the awareness of gaming disorder and related prevention skills. (2) Psychological well-being and healthy family functioning are protective factors for gaming disorder. Prevention programmes should focus on improving adolescent psychological well-being and psychological skills including interpersonal communication, emotional management and stress management skills. The involvement of family is especially important and should be stressed. Healthy family structure and function, good family relationships and communication, as well as psychological well-being of teenagers are all helpful for preventing gaming disorder. (3) Schools and parents should monitor teenagers' gaming behaviours, and it is very important for early detection and early intervention. Professional help is needed for those with gaming disorders. (4) The related research should be strengthened and standardised clinical services should be provided for gaming disorders. Guidelines on the diagnoses and treatment of gaming disorders are urgent for specialised treatment and recovery facilities. (5) The related government departments should lead the establishment and regulations 
from a public health point of view. The related parties including education, propaganda, mental health and psychology, as well as the gaming industry should jointly work together to take comprehensive prevention strategies such as developing game rating systems, supervising gaming behaviours, developing self-screening tools for gaming disorder and evidencebased interventions.

Contributors MZ wrote the draft. WH proof-read the draft.

Funding The authors have not declared a specific grant for this research from any funding agency in the public, commercial or not-for-profit sectors.

Competing interests None declared.

Patient consent for publication Not required.

Provenance and peer review Not commissioned; externally peer reviewed.

\section{(2) \\ OPEN ACCESS}

Open access This is an open access article distributed in accordance with the Creative Commons Attribution Non Commercial (CC BY-NC 4.0) license, which permits others to distribute, remix, adapt, build upon this work non-commercially, and license their derivative works on different terms, provided the original work is properly cited, appropriate credit is given, any changes made indicated, and the use is non-commercial. See: http://creativecommons.org/licenses/by-nc/4.0/.

(C) Author(s) (or their employer(s)) 2018. Re-use permitted under CC BY-NC. No commercial re-use. See rights and permissions. Published by BMJ.

D) Check for updates

To cite Zhao M, Hao W. General Psychiatry Epub ahead of print: [please include Day Month Year]. doi:10.1136/ gpsych-2019-100086

Received 8 May 2019

Accepted 16 May 2019

General Psychiatry 2019;32:e100086. doi:10.1136/gpsych-2019-100086

ORCID iD
Min Zhao http://orcid.org/0000-0002-4551-043X

REFERENCES

1 World Health Organisation. International Classification of disease, eleventh revision (ICD-11), 2018. Available: https://icd.who.int/ dev11/l-m/en [Accessed 8 May 2018].

2 Weinstein A, Livny A, Weizman A. New developments in brain research of Internet and gaming disorder. Neurosci Biobehav Rev 2017;75:314-30.

3 Widyanto L, Griffiths M. Chapter 6-internet addiction: does it really exist? In: Psychology \& the Internet. Academic press, 2007:141-63.

4 Chen Q, Quan X, HM L, et al. Comparison of personality and other psychological factors between students with and without impairment of social function. Shanghai Arch Psychiatry 2015;27:36-41.

5 Bargeron AH, Hormes JM. Psychosocial correlates of Internet gaming disorder: psychopathology, life satisfaction, and impulsivity. Comput Human Behav 2017;68:388-94.

6 Jiang D, Zhu S, Ye M, et al. A cross-sectional survey of Internet addiction among college students in wenzhou and its Tridimensional personality. Shanghai Arch Psychiatry 2012;24:99-107.

7 King DL, Delfabbro PH, Wu AMS, et al. Treatment of Internet gaming disorder: an international systematic review and consort evaluation. Clin Psychol Rev 2017;54:123-33.

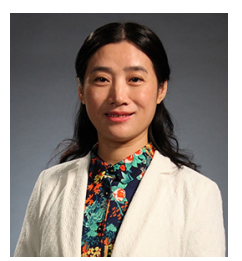

Min Zhao, Ph.D $\mathcal{E}$ MD, a professor in psychiatry and the vice president of Shanghai Mental Health Center. Dr. Zhao has been engaged in clinical, teaching and scientific research in psychiatry and substance abuse since 1996. She has received more than 20 national and international research grants from the WHO and NIH. She has published over 200 peer-reviewed articles and 6 books comprising 30 book chapters. She is on the editorial board of peer review journals including Addiction and Cochrane Database of Systematic Reviews. She is a member of the informal scientific group of UNODC, and a member of the international advisory group and FSCG of ICD-11 mental, behavioural and neurodevelopmental disorders (MBD) and led the field study of ICD-11 MBD in China. 